\section{TAXONOMY OF MERULIUS EUROCEPHALUS (BERK. \& BR.) PETCH V/S BONDARZEWIA BERKELEYI (FR.) BOND. \& SING. (BASIDIOMYCOTA: AGARICOMYCETES): SYNONYM STATUS REVIEWED}

\author{
Manoj Kumar ${ }^{1} \&$ Nirmal Sudhir Kumar Harsh ${ }^{2}$ \\ ${ }^{1,2}$ Forest Pathology Division, Lab No. 34, Forest Research Institute, \\ New Forest Campus, Dehradun Uttarakhand 248006, India \\ ${ }^{1}$ mnoj23@gmail.com (corresponding author), ${ }^{2}$ harshnsk@icfre.org
}

During a study of polypores in northern India we came across the descriptions of two morphologically dissimilar species: Merulius eurocephalus (Berk. and $\mathrm{Br}$.) Petch and Bondarzewia bekeleyi (Fr.) Bond. \& Sing. which are being treated as synonyms (Mycobank, CBSKNAW Fungal Biodiversity Centre). A third species Merulius similis was also taken into consideration which has been treated as a synonym of Merulius eurocephalus (Petch 1910; Bakshi 1971; Corner 1971). A comparative analysis of the descriptions of the three fungi and an examination of the available specimens was made to draw a conclusion in the present study.

Materials and Methods: Literature regarding two species under reference was thoroughly reviewed for comparison of morphological, microscopic and cultural characters (Petch 1910; Saccardo 1944; Nobles 1948; Boedijn 1951; Bakshi 1971; Corner 1971; Ginns 1971; Sen 1973; Rattan 1977; Stalpers 1978; Ryvarden \& Johansen 1980; Ryvarden 1984, 1991). Specimens examined for comparison were M. eurocephalus (FPD/ FRI-8628) deposited at Forest Pathology Herbarium
Forest Research Institute, a new specimen collected (FPD/FRI-8670) and a specimen (NEHU-M303) received from Shillong, Meghalaya.

The macroscopic and microscopic examination in the study follows the descriptions and terminology as used by Ryvarden \& Johansen (1980).

Material examined: FPD/FRI8628, sporophore sessile, brittle, dry, shrunken, $12 \times 15 \times 0.5 \mathrm{~cm}$;

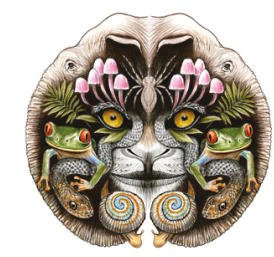

ISSN 0974-7907 (Online) ISSN 0974-7893 (Print)

\section{OPEN ACCESS}

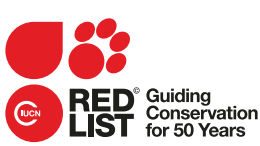
upper surface dark brown due to heavy deposition of spores, white in some areas, glabrous, uneven; margin folded, unequal, thick; context cream colour, soft thin, zonation not seen, very thin as it is dried $(0.4 \mathrm{~cm})$; hymenial surface rusty brown, pores merulioid, 1-2 per $\mathrm{mm}$; basidia not seen, basidiospores yellow ovoid, slightly thick walled, apiculte, 4-5.5×3.2-3.8 $\mu \mathrm{m}$; hyphal system dimitic, difficult to observe due to heavy spore deposition, generative hyphae hyaline, thin walled, branched, with clamp, 1.5-6 $\mu \mathrm{m}$ in diameter, skeletal hyphae thick-walled, solid, 1.5-3.5 $\mu \mathrm{m}$ in diameter. Determined as Serpula similis (Berk. \& Br.) Ginns (=Merulius eurocephalus Berk. \& Br.)

Submitted as Merulius eurocephalus Berk. \& Br.; Host: Thyrsostachys oliveri Gamble (Bamboo), Sept. 1986; by Sujan Singh. Locality: Central Terai Forest Division Haldwani, Uttarakhand (erstwhile Uttar Pradesh) India.

FPD/FRI-8670, sporophore annual, effused-reflexed, sessile imbricate, fleshy watery when fresh due to absorption of rain water, becomes rigid when somewhat dry, shrinking, $15 \times 9 \times 2 \mathrm{~cm}$; upper surface white to light

DOI: http://dx.doi.org/10.11609/JoTT.04054.6585-9

Editor: Hayrünisa Baş Sermenli, Muğla University, Kötekli, Turkey.

Date of publication: 26 November 2014 (online \& print)

Manuscript details: Ms \# 04054 | Received 07 June 2014 | Final received 25 August 2014 | Finally accepted 27 October 2014

Citation: Kumar, M. \& N.S.K. Harsh (2014). Taxonomy of Merulius eurocephalus (Berk. \& Br.) Petch v/s Bondarzewia berkeleyi (Fr.) Bond. \& Sing. (Basidiomycota: Agaricomycetes): synonym status reviewed. Journal of Threatened Taxa 6(12): 6585-6589; http://dx.doi.org/10.11609/JoTT.04054.6585-9

Copyright: (C Kumar \& Harsh 2014. Creative Commons Attribution 4.0 International License. JoTT allows unrestricted use of this article in any medium, reproduction and distribution by providing adequate credit to the authors and the source of publication.

Funding: Indian Council of Medical Research (ICMR) New Delhi under the research fellowship programme (ICMR-JRF) [3/1/3/JRF-2010/HRD-64 (31516)]

Competing Interest: The authors declare no competing interest.
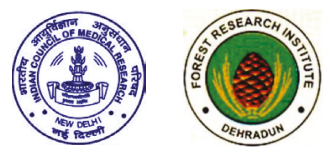

Acknowledgements: The current study is supported by Forest Research Institute (FRI), Dehradun and funded by Indian Council of Medical Research (ICMR), New Delhi under the Research Fellowship Programme. 
yellow, the surface becomes light yellowish-brown due to heavy deposition of spores from the fruit bodies situated above it when growing in imbricate clusters, glabrous uneven; margin rounded, unequal thick; context white or cream colour, azonate, 2-3 cm thick, cheesy, elastic threads form on tearing, Hymenial surface mustered yellow in the beginning turns ochre to umber at a later stage, shallow, angular unequal, merulioid, 1-2 per $\mathrm{mm}$, up to $2 \mathrm{~mm}$ long; Basidia persistent, narrow club shaped, 7-8 $\mu \mathrm{m}$ broad; Basidiospores bright yellow to ochre, ovoid slightly thick walled, apiculate, 4.5-5.5x3.5-3.8 $\mu \mathrm{m}$; Hyphal system dimitic; generative hyphae hyaline, thin walled branched, with clamps, 1.8-7 $\mu$ m diameter and skeletal hyphae nearly hyaline, thick walled, some with obliterated lumen, ends tapering, 4-5 $\mu \mathrm{m}$ diameter.

Determined as Serpula similis (Berk. \& Br.) Ginns (=Merulius eurocephalus Berk. \& Br.) (=Merulius similis Berk. \& Br.) (Image 1)

12.viii.2013 by Manoj Kumar. Host Cupressus cashmeriana Royle ex. Carriere. Locality New Forest Campus, Forest Research Institute Dehradun, India $\left(30^{\circ} 20^{\prime} 38.04^{\prime \prime} \mathrm{N} \& 77^{\circ} 59^{\prime} 44.94^{\prime \prime} \mathrm{E}\right)$. This specimen has a specific soothing spicy smell which is not mentioned by earlier workers.

NEHU-M303, sporophore stipitate, developed from underground sclerotium, stipe branched, up to $6 \mathrm{~cm}$ long and $3.5 \mathrm{~cm}$ thick, pileus imbricate, fan shaped $14 \times 22.5 \times 3$ $\mathrm{cm}$, upper surface with tinge of tan, azonate, finely tomentose, margin concolorous, thick; context pale buff, azonate, corky, up to $2 \mathrm{~cm}$ thick, tube layer concolorous and continuous with the context, decurrent on the stipe, up to $1 \mathrm{~cm}$ thick; hymenial surface tan, dried specimen has blackish hymenium, the pores circular to angular, 1-2 per $\mathrm{mm}$, with thick dissepiments that are lacerate; Hyphal system dimitic, generative hyphae hyaline, thin walled, simple-septate, branching not seen, 3.2-6 $\mu \mathrm{m}$ in diameter, skeletal hyphae thick-walled, 2-12 $\mu \mathrm{m}$ in diameter. basidia clavate, 4-sterigmate, 40-50x8-12 $\mu \mathrm{m}$, simple-septate at the base, basidiospores globose to subglobose, hyaline, echinulate, 5-6 $\mu \mathrm{m}$.

Determined as Bondarzewia berkeleyi (Fr.) Bond. \& Sing. (Image 2)

09.x.2011 by Aroma Lyngdoh. Host buried wood (probably oak wood). Locality Mawphlong Sacred Grove, East Khasi Hills District, Shillong, Meghalaya, India $\left(25^{\circ} 28^{\prime} 09.74^{\prime \prime} \mathrm{N} \& 91^{\circ} 46^{\prime} 31.04^{\prime \prime} \mathrm{E}\right)$.

Result: From the above description it is clear that the two species, M. eurocephalus and B. berkeleyi, mentioned differ macroscopically as well as microscopically.

Cultural studies by Nobles (1948), Sen (1973) and Stalpers (1978) also throw some light on the differences between the two species. Sen (1973) has described cultural characteristics of $M$. eurocephalus which is similar to $M$. similis described by Banerjee \& Mukhopadhyay (1962). Stalpers (1978) has done a cultural study of $B$. berkeleyi. He has also mentioned that the culture of $M$. similis has been described under the name of $M$. eurocephalus. The main differences are summarised in Table 1.

Discussion: Petch (1910) described Merulius eurocephalus (Berk. \& Br.) Petch found on bamboo. This species has been treated under the valid name of Bondarzewia berkeleyi (Fr.) Bond. \& Sing. (Mycobank, CBS-KNAW Fungal Biodiversity Centre). The examined specimens were identified on the basis of descriptions given by Bakshi (1971) and found that the species were confirmed with the description of $M$. eurocephalus given by Petch (1910), Bakshi (1971) and Corner (1971) but was quite dissimilar with the description given by Ryvarden \& Johansen (1980) for the species $B$. berkeleyi. The most striking difference between the two species was of spores. The former has subglobose to ovoid bright yellow smooth spores while the latter has hyaline asperulate spores. Culture studies by Nobles (1948), Banerjee \& Mukhopadhyay (1962), Sen (1973) and Stalpers (1978) were also helpful in determining the differences between the two species. So the two species are not synonymous as given in Mycobank but are two different species.

The species Polyporus eurocephalus Berk. \& Br. was established by Berkeley \& Broome (1874) but its full description could not be found, only fruiting body characters have been mentioned (Saccardo 1944). It was changed to (adopted as) M. eurocephalus (Berk. \& Br.) Petch by Petch (1910) who had first given the full description of the fungus in Annals of Royal Botanic Gardens Peradeniya as parasitic to bamboo plants and gave $P$. eurocephalus, Polyporus sulfureus and $M$. similis

Table 1. Cultural characteristic differences between Merulius eurocephalus Berk. \& Br. \& Bondarzewia berkeleyi (Fr.) Bond. \& Sing.

\begin{tabular}{|c|l|l|}
\hline & $\begin{array}{l}\text { Merulius eurocephalus Berk. \& } \\
\text { Br. (=Merulius similis Berk. \& Br.) }\end{array}$ & $\begin{array}{l}\text { Bondarzewia berkeleyi (Fr.) } \\
\text { Bond. \& Sing. }\end{array}$ \\
\hline 1 & $\begin{array}{l}\text { Spores are not produced in } \\
\text { culture }\end{array}$ & $\begin{array}{l}\text { Produces spores similar to } \\
\text { basidiospores (conidiospores) on } \\
\text { irregularly shaped, sterigmate } \\
\text { sporogenous cells in culture }\end{array}$ \\
\hline 2 & Conidiogenous vesicles absent & Conidiogenous vesicles present \\
\hline 3 & Hyphal clamps absent & Hyphal clamps present \\
\hline 4 & $\begin{array}{l}\text { Submerged and aerial mycelium } \\
\text { branched }\end{array}$ & Hyphae not branched \\
\hline 5 & Hyphae not with incrustation & Hyphae with incrustation \\
\hline
\end{tabular}




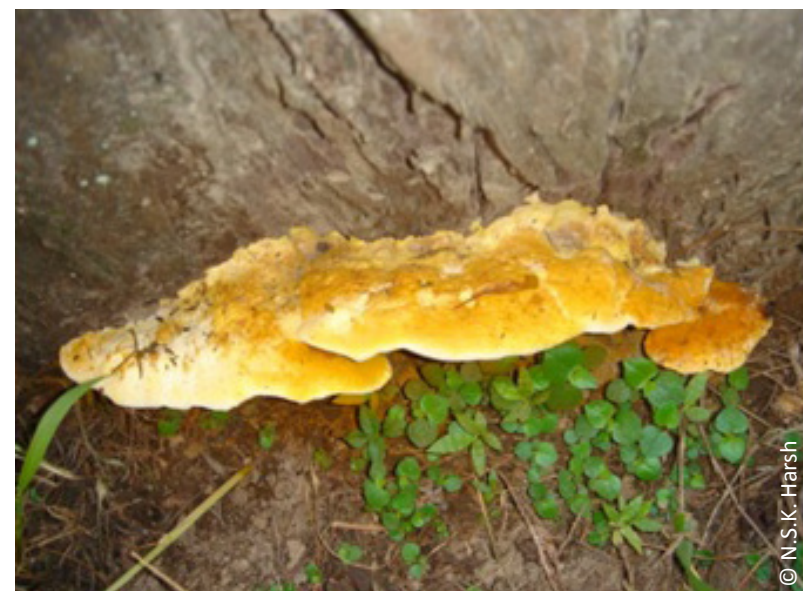

Image 1. Serpula similis

as its synonyms. Berkley \& Broome (1874) had also described another species Merulius similis Berk. \& Br. which was considered as a synonym of $M$. eurocephalus by Petch (1910), Bakshi (1971) and Corner (1971). Cooke (1957) described another species with the name Serpula eurocephala (Berk. \& Br.) Cooke under coloured spore category as are $M$. eurocephalus and $M$. similis and gave Polyporus eurocephalus, Merulius similis, Polyporus sulfureus Fr. sensu Berk. \& Br., M. eurocephalus, Merulius pseudolacrymans Henn., Merulius binominatus Massee, Merulius consimilis Lloyd, Merulius giganteus Sauter, Merulius insignis Wakefield, Merulius sessilis Berk. \& Br. f. Pileata Bres., Merulius subambiguus Henn., Merulius tessellates Bres. as its synonyms. However, according to Ginns (1971) it was misidentified by Cook. He said that the type (K) he studied had asperulate spores. Later on it was synonymsed with B. berkeleyi (Ginns 1976). He also separated the species with hyaline spores in Merulius while the species with coloured spores was shifted to Serpula by Burt (1917) and Ginns (1968) and Merulius similis has been given the valid name of Serpula similis (Berk. \& Br.) Ginns by Ginns (1971).

It appears that the confusion started with the observations made by Boedijn (1951) while describing Bondarzewia berkeleyi. He had mentioned that the type of $P$. eurocephalus at Kew was in bad shape and he saw the specimen at Herbarium of Bresadola at Stockholm with label written $P$. eurocephalus $=P$. berkeleyi. He has stated that as he could not see any difference with Polyporus berkeleyi and $P$. eurocephalus, he considered $P$. eurocephalus as a synonym of $P$. berkeleyi. Petch (1910) while describing $M$. eurocephalus mentioned that the type specimen of $P$. eurocephalus kept at Peradeniya was reported to be parasitized by Hypomyces and its

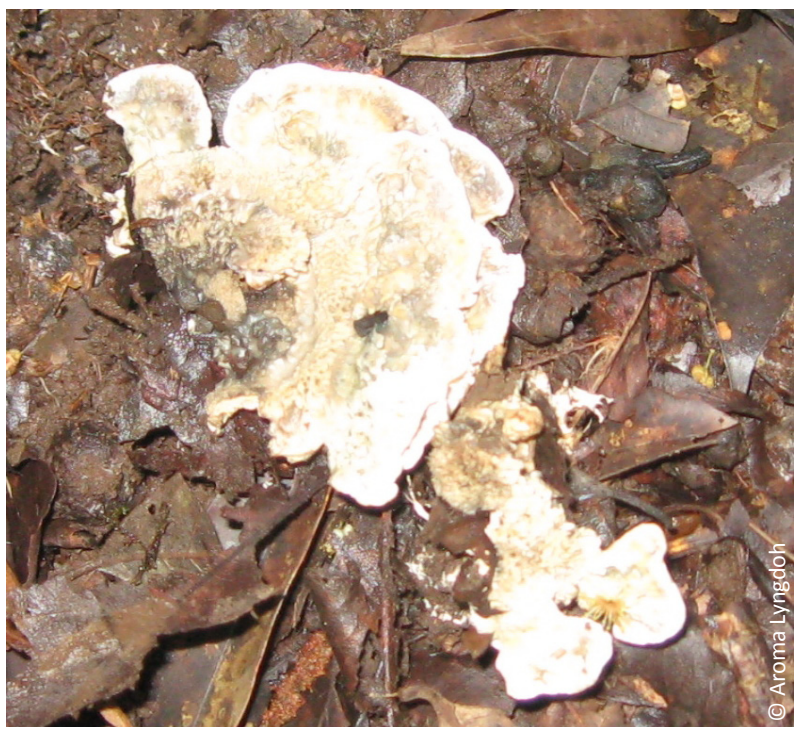

Image 2. Bondarzewia berkeleyi

tubes were filled with globose spores of 5-7 $\mu$, covered with a close set of spines. So, it is possible that the actual specimen might not have been studied. Ryvarden \& Johansen (1980) under the description of B. berkeleyi have treated $P$. eurocephalus as synonym. Ryvarden (1984) while conducting a series of type studies in the Polyporaceae examined the polypores described by Berkeley, either alone or together with other mycologists treated Polyporus eurocephalus Berk. \& Br. as a synonym of B. berkeleyi. Ryvarden (1991) retained this synonym in his work 'Nomenclature and Taxonomy of Polypores'. Due to synonymy with $P$. eurocephalus; $M$. eurocephalus might be considered as the synonym of B. berkeleyi. Vaidya \& Rabba (1993) while giving an account of valid names of Indian wood decaying fungi had shown $M$. eurocephalus as synonymous to $B$. berkeleyi quoting Ryvarden (1991). It seems after this the synonymity of $M$. eurocephalus was retained with $B$. berkeleyi and continued in subsequent work in India.

M. similis was reported from India in the early $20^{\text {th }}$ century as $M$. pseudolacrymans from Saharanpur on tree roots by Hennings (1901). Bose (1919) reported it from Hoogly causing decay in exposed roots of Bambusa. This fungus was also reported on Bambusa arundinacea and B. flabelifer near Calcutta by Banerjee (1947) and from Nainital by Mitter \& Tandon (1932). Banerjee \& Mukhopadhyay (1962) studied M. similis and associated bamboo-rot. Bakshi (1971) gave its description as growing on the roots of living and dead bamboo. $M$. similis is known from tropical regions in Africa and South-east Asia, where it is usually found on Bamboo 
and hardwoods (Ginns 1971; Carlier et al. 2004). There were also some reports where fungi on bamboo have been reported either as $M$. eurocephalus or $M$. similis (Khan et al. 1995; Mohanan 1997; Panda 2011; Lee et al. 2012). It appears that the parasitic fungi of bamboo were treated as $M$. eurocephalus or $M$. similis or both as synonyms of each other.

Recently, a sample from northeastern India (Shilong, Meghalaya) was identified as $B$. berkeleyi on the basis of characters described by Ryvarden \& Johansen (1980). We did not find earlier records (Bilgrami et al. 1979, 1981, 1991; Jamaluddin et al. 2004) of B. berkeleyi or its synonym from India. M. eurocephalus has long been treated as $B$. berkeleyi before we found it as a distinct species and previous reports were only synonyms given to $M$. eurocephalus which was not correct as discussed above. The fungus reported on Cupressus cashmeriana from Forest Research Institute, Dehradun is Serpula similis as a new host record as earlier it was reported on bamboo and hardwoods (Ginns 1971; Carlier et al. 2004).

Conclusion: The basidiospore morphology of Bondarzewia berkeleyi, i.e., globose and ornamented with spines closely resembles the basidiospores of Russula and Lactarius instead of the smooth, elliptical or cylindrical spores of most other polypores. Recent molecular studies have confirmed this suspected close association between these groups and have placed the genus Bondarzewia in the Russulales (Miller et al. 2006). Molecular studies have shown that Serpula have diverged from Tapinelliae (Skrede et al. 2011). Serpula similis has not been extensively studied for molecular aspects as its other sister lineages like Serpula lacrymans (Wulfen) J. Schröt. The branch in the phylogenetic tree leading to $S$. similis is very long, indicating an increased rate of molecular evolution (Skrede et al. 2011). Three Serpula species S. incrasata (Berk. \& M.A. Curtis) Donk, S. similis and S. pulverulenta are oldest species within Serpulaceae family (Skrede et al 2011). The relationship between Serpula and ectomycorrhizal fungi Austropaxillus Bresinsky \& Jarosch and Gymnopaxillus Horak is already established (Hallenberg \& Eriksson 1985). Traditionally, Serpula has been recognised as member of Coniophoraceae (Donk 1948; Jarosch 2001) while molecular results showed it to be distantly related (Skrede et al 2011).

On the basis of the study of the available specimens and review of literature discussed above; we suggest that $M$. eurocephalus should not be treated as a synonym of $B$. berkeleyi but should be treated as $M$. similis under the valid name of the species as Serpula similis (Berk.
\& Broom) Ginns. Literature regarding change of $M$. eurocephalus to $B$. berkeleyi should be reviewed so that the confusion prevailing over the synonyms can be overcome.

\section{References}

Bakshi, B.K. (1971). Indian Polyporaceae (On Trees and Timbers). ICAR Publication, New Delhi, 246pp.

Banerjee, S. \& S. Mukhopadhyay (1962). A study on Merulius similis B. \& Br. and the associated Bamboo rot. Ostereichische Botanische Zeitschrist 109(3): 197-212.

Banerjee, S.N. (1947). Fungous flora of Calcutta and suburbs. I. Bulletin of Botanical Society of Bengal 1: 37-54.

Berkeley, M.J. \& C.E. Broome (1874). Enumeration of the fungi of Ceylon. Part II. Botanical Journal of the Linnean Society 14: 29-141.

Bilgrami, K.S., Jamaluddin \& M.A. Rizvi (1979). The Fungi of India. Part I. List and Refernces. Today and Tomorrow Printers and Publishers, New Delhi, 467pp.

Bilgrami, K.S., Jamaluddin \& M.A. Rizvi (1981). The Fungi of India. Part II. Host Index and Addenda. Today and Tomorrow Printers and Publishers, New Delhi, 268pp.

Bilgrami, K.S., Jamaluddin \& M.A. Rizvi (1991). The Fungi of India. Part II - 2nd Edition. List and Refernces. Today and Tomorrow Printers and Publishers, New Delhi, 798pp.

Boedijn, K.B. (1951). Sydowia. Annals Mycologici Editi in Notiam Scientiae Mycologicae Universalies 2(5): 1-19.

Bose, S.R. (1919). Description of fungi in Bengal. Proceedings of the Indian association of Cultural Science 4: 109.

Burt, E.A. (1917). Merulius in North America. Annals of the Missouri Botanical Garden 4(4): 305-362.

Carlier, F.X., A. Bitew, G. Castillo \& C. Decock (2004). Some Coniophoraceae (Basidiomycetes, Boletales) from the Ethiopian highlands: Coniophora bimacrospora sp. nov. and a note on the phylogenetic relationships of Serpula similis and Gyrodontium. Cryptogamie, Mycologie 25: 261-275.

Cooke, W.B. (1957). The Genera Serpula and Meruliporia. Mycologia 49: 197-225; http://dx.doi.org/10.2307/3755630

Corner, E.J.H. (1971). Merulioid Fungi in Malaysia. Gardens Bulletin Singapore 25: 355-381.

Donk, M.A. (1948). Notes on Malesian Fungi 1. Bulletin of the Botanic Gardens Buitenzorg 3: 473-482.

Ginns, J.H. (1968). The Genus Merulius I. Species proposed by Burt. Mycologia 60(6): 1211-1231.

Ginns, J.H. (1971). The genus Merulius IV. Species proposed by Berkeley, by Berkeley \& Curtis and by Berkeley \& Broome. Mycologia 63: 219-236.

Ginns, J.H. (1976). Merulius: s.s. and s.l., taxonomic disposition and identification of species. Canadian Journal of Botany 54(1-2): 100167; http://dx.doi.org/10.1139/b76-014

Hallenberg, N. \& J. Eriksson (1985). The Lachnocladiaceae and Coniophoraceae of North Europe. Oslo, Fungiflora A/S (Cross Ref.).

Hennings, P. (1901). Fungi Indiae orientalis. II. Hedwigia 40: 323-342. Jamaluddin, M.G. Goswami \& B.M. Ojha (2004). Fungi of India (19892001). M/S Scientific Publishers India, 326pp.

Jarosch, M. (2001). Zur Molekularen Systematik der Boletales: Coniophorineae, Paxillineae und Suillineae. Berlin-Stuttgart: J. Cramer 191pp.

Khan, S.N., B.M. Mishra \& K.K. Tiwari (1995). New host records of Pathogenic Fungi from India. Indian Journal of Forestry 18: 89-92.

Lee, S.S., S.A. Alias, E.G.B. Jones, N. Zainuddin \& H.T. Chan (2012). Checklist of Fungi of Malaysia. Research Pamplet No. 132. Swan Printing Sdn. Bhd., Seri Kembangan Malaysia, 980pp.

Miller, S.L., E. Larssen, K.H. Larssen, A. Verbeken \& J. Nuytinck (2006). Perspectives in the new Russulales. Mycologia 98(6): 960-970.

Mitter, J.H. \& R.N. Tandon (1932). Fungus Flora Nainital I. Journal of Indian Botanical Society 11: 178-180. 
Mohanan, C. (1997). Diseases of Bamboo in Asia. Brill Academic Publishers, 228pp.

Nobles, M.K. (1948). Studies in forest pathology VI. Identification of cultures of wood-rotting fungi. Canadian Journal of Forest Research 26: $281-431$.

Panda, H.C. (2011). Bamboo Plantation and Utilization Handbook. Asia Pacific Business Press Inc., New Delhi, 568pp.

Petch, T. (1910). Revisions of Ceylon fungi (Part II). Annals of the Royal Botanic Gardens Peradeniya 4: 373-444.

Rattan, S.S. (1977). Resupinate Aphyllophorales of North Western Himalayas. Bibliotheca Mycologica 60: 1-427.

Ryvarden, L. (1984). Type studies in Polyporaceae 16. Species described by J.M. Berkeley, either alone or with other mycologists from 1856 to 1886. Mycotaxon 20: 329-363.

Ryvarden, L. (1991). Genera of Polypores. Nomenclature and Taxonomy. Synopsis Fungorum 5. Fungiflora, Oslo, Norway, 363pp. Ryvarden, L. \& I. Johansen (1980). A Preliminary Polypore Flora of East Africa. Fungiflora, Oslo Norway, 636pp.
Saccardo, P.A. (1944). Sylloge Fungorum, Omnium Hucuque cognitorum. Published by Edwards Brothers, Inc. Ann Arbor Michigan 6(25): 1-929.

Sen, M. (1973). Cultural diagnosis of Indian Polyporaceae. 3. Genera Daedalea, Favolus, Ganoderma, Hexagonia, Irpex, Lenzites, Merulius and Poria. - Indian Forest Records, Forest Pathology 2: 277-304.

Skrede, I., I.B. Engh, M. Binder, T. Carlsen, H. Kauserud \& M. Bendiksby (2011). Evolutionary history of Serpulaceae (Basidiomycota): molecular phylogeny, historical biogeography and evidence for a single transition of nutritional mode. BMC Evolutionary Biology 11: 230; http://dx.doi.org/10.1186/1471-2148-11-230

Stalpers, J.A. (1978). Identification of wood inhabiting Aphyllophorales in pure culture. Studies in Mycology 16: 1-248.

Vaidya, J.G. \& A.S. Rabba (1993). Valid names for some common Indian wood rotting polypores, their synonyms and authenticity - II. Journal of the Indian Academy of Wood Science 24: 35-56.

Wiliv 